\title{
Modeling of the Interannual Variation in Ecosystem Respiration of a Semiarid Grassland
}

\author{
Tomoko Nakano ${ }^{1}$ and Masato Shinoda ${ }^{2}$ \\ ${ }^{1}$ Department of Economics, Chuo University, Higashi-nakano, Hachioji, Tokyo, \\ ${ }^{2}$ Arid Land Research Center, Tottori University, Hamasaka, Tottori
}

Japan

\section{Introduction}

The Mongolian steppe zone comprises a major part of the East Asian grasslands. The regional climate is typically continental and semiarid, with low precipitation and large diurnal and annual temperature fluctuations. Rainfall normally occurs during the warm season (i.e., summer), but large interannual variability in the amount and pattern of rain has been observed and the area has often suffered from droughts.

Respiratory $\mathrm{CO}_{2}$ efflux from terrestrial ecosystems (ecosystem respiration, $\mathrm{R}_{\text {eco }}$ ) is an important component of the global carbon cycle, and since $R_{\text {eco }}$ includes soil respiration (both root respiration and heterotrophic microbial decomposition) as well as aboveground respiration, rates of $R_{\text {eco }}$ depend on complex interactions between biotic and abiotic factors. In general, temperature has been recognized as the major regulator of $R_{\text {eco }}$ (Fang \& Moncrieff, 2001; Lloyd \& Taylor, 1994). Although many temperature models have been proposed, the simplest is the so-called exponential $\mathrm{Q}_{10}$ relationship (van't Hoff model), whereby the parameter $Q_{10}$ represents the factor by which the respiration rate increases with a $10^{\circ} \mathrm{C}$ temperature increase. Soil water is also an important variable controlling $R_{\text {ecor }}$ especially in semiarid and arid regions (e.g., Davidson et al., 1998; Hunt et al., 2002; Wen et al., 2006; Xu \& Qi, 2001). Studies have shown that both very low and very high water content reduces ecosystem and soil respiration via the direct inhibition of biological activity or the inhibition of oxygen diffusion, respectively (Davidson et al., 1998; Gaumont-Guay et al., 2006; Wen et al., 2006). An increasing number of studies have indicated that $R_{\text {eco }}$ rates are positively correlated with features of plant productivity such as the photosynthetic rate, leaf area index, and dry weight of green biomass (e.g., Aires et al., 2008; Crain et al., 1999; Jassal et al., 2008; Sampson et al., 2007).

Grassland ecosystems in semiarid regions demonstrate a sensitive response to climate changes, especially to changes in precipitation (Miyazaki et al., 2004; Ni, 2003; Shinoda et al., 2010), suggesting that interannual climate variability can lead to major changes in the respiratory $\mathrm{CO}_{2}$ release from the ecosystem. Studies have demonstrated that the ecosystem switches from a net carbon sink during non-drought years to a net carbon source in drought years (Aires et al., 2008; Meyers, 2001).

We conducted field measurements of $\mathrm{CO}_{2}$ fluxes and environmental parameters in a semiarid grassland area of Mongolia since 2004 and have quantitatively documented the 
dependence of ecosystem respiration on environmental variables (Nakano \& Shinoda, 2010; Nakano et al., 2008). Based on our findings, we constructed an empirical respiration model in which the rates of ecosystem respiration are calculated from the soil temperature, soil water content, and aboveground biomass (AGB) (Nakano \& Shinoda, 2010). In the present study, interannual changes in ecosystem respiration during the growing seasons from 2007 to 2010 at the semiarid grassland site in Mongolia were estimated using this model. We assessed whether temperature, moisture, or plant biomass was the most important environmental parameter controlling interannual variability in ecosystem respiration.

\section{Methods}

\subsection{Study site and field measurements}

Our study sites were located in grassland areas in central Mongolia (Fig. 1), which contain typical steppe vegetation that is grazed by livestock. The plant community at the area consists of graminaceous perennial grasses (Agropyron cristatum, Cleistogenes squarrosa, Stipa krylovii), forbs (Artemisia adamsii, Chenopodium spp.), and small shrubs (Caragana spp.). Soils are classified as Kastanozems (IUSS Working Group WRB, 2006), which is widely distributed in the Mongolian steppes. The bulk density of the upper $5 \mathrm{~cm}$ of the soil profile is approximately $1.5 \mathrm{~g} \mathrm{~cm}^{-3}$.

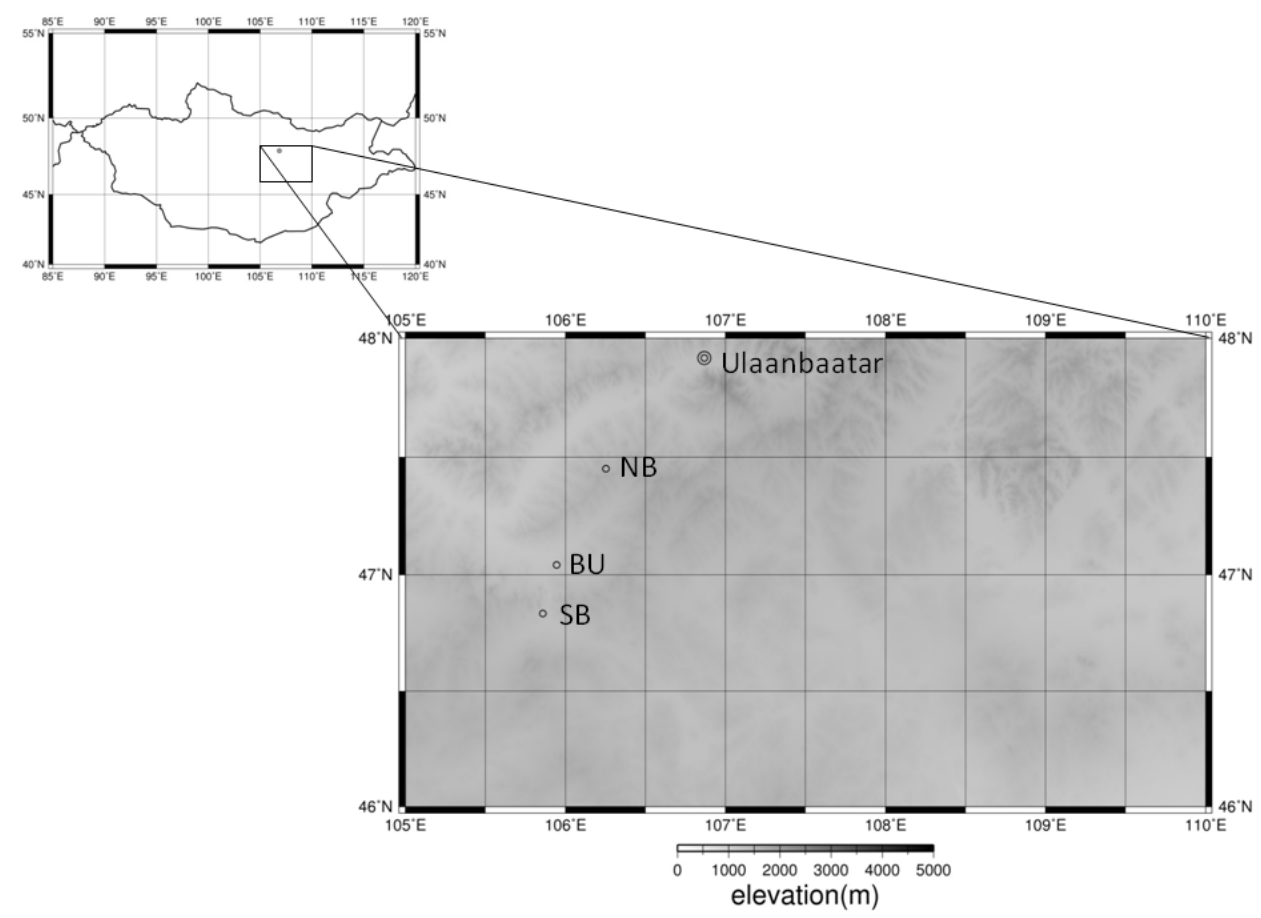

Fig. 1. Study site locations in semiarid grassland areas of central Mongolia 
Site BU [47 $02^{\prime} 37.2^{\prime \prime} \mathrm{N}, 105^{\circ} 57^{\prime} 04.9^{\prime \prime} \mathrm{E}, 1200 \mathrm{~m}$ above sea level (asl)] was established in 2004 in Bayan Unjuul county, which has an Institute of Meteorology and Hydrology of Mongolia (IMH) meteorological station. Data from the IMH station indicated that the mean annual air temperature and precipitation from 1995 to 2010 were $0.3^{\circ} \mathrm{C}$ and $155.8 \mathrm{~mm}$, respectively. Most of the precipitation occurred between May and August. Two additional sites were established in 2009 and 2010: site NB, located approximately $60 \mathrm{~km}$ north of site BU $\left(47^{\circ} 27^{\prime} 02.1^{\prime \prime} \mathrm{N}, 106^{\circ} 15^{\prime} 09.2^{\prime \prime} \mathrm{E}, 1507 \mathrm{~m}\right.$ asl) and site $\mathrm{SB}$, located approximately $30 \mathrm{~km}$ south of site BU (46 $50^{\prime} 01.4^{\prime \prime} \mathrm{N}, 105^{\circ} 51^{\prime} 31.2^{\prime \prime} \mathrm{E}, 1296 \mathrm{~m}$ asl).

The rate of $R_{\text {eco }}$ was measured using a closed-chamber technique during the growing seasons of 2004, 2005, 2006, 2009, and 2010 at site BU, in 2010 at site NB, and in 2009 and 2010 at site SB. We set up automated weather and ground observation systems at site BU in June 2004, and standard meteorological and soil parameters were continuously measured at 30-minute intervals. Meteorological and soil parameters were measured at sites NB and SB with a portable weather station and soil temperature and moisture sensors for each flux measurement period. Live AGB was measured by clipping green parts of the vegetation and oven-drying them at $80^{\circ} \mathrm{C}$ for 48 hours. The AGB was determined at each point where the closed-chamber measurements were made. The details and results of these measurements are described by Nakano et al. (2008) and Nakano \& Shinoda (2010).

\subsection{Respiration model}

An empirical respiration model for which the rates of ecosystem respiration are calculated using the soil temperature, soil water content, and AGB, was constructed based on the field measurement results (Nakano \& Shinoda, 2010). In the model, the rates of $R_{\text {eco }}$ were calculated using the following equation (van't Hoff-type model):

$$
\mathrm{R}_{\text {eco }}=\mathrm{R}_{20} \mathrm{Q}_{10}(\mathrm{Ts}-\mathrm{Tref}) / 10,
$$

where $R_{20}$ is the standardized rate of respiration $\left(\mu \mathrm{mol} \mathrm{m} \mathrm{m}^{-2} \mathrm{~s}^{-1}\right)$ at the reference temperature $\left(20^{\circ} \mathrm{C}\right), \mathrm{Q}_{10}$ is the factor by which the respiration rate increases for each $10^{\circ} \mathrm{C}$ increment increase in temperature (dimensionless), $\mathrm{T}_{\mathrm{s}}$ is the soil temperature $\left({ }^{\circ} \mathrm{C}\right)$ at $5 \mathrm{~cm}$ depth, and $\mathrm{T}_{\text {ref }}$ is the reference temperature of $20^{\circ} \mathrm{C}$.

Nakano \& Shinoda (2010) revealed that $\mathrm{R}_{20}$ values can be expressed as the linear model of AGB (Eq. 2), the residuals of which are calculated from the soil water content (Eq. 3),

$$
\begin{gathered}
\mathrm{R}_{20}=\mathrm{a}_{1} \mathrm{AGB}+\mathrm{a}_{2,} \\
\text { Residual }+2.0=\exp \left(\mathrm{a}_{3} \mathrm{~W}^{2}+\mathrm{a}_{4} \mathrm{~W}+\mathrm{a}_{5}\right),
\end{gathered}
$$

where $a_{1}, a_{2}, a_{3}, a_{4}$, and $a_{5}$ are parameters, AGB is the aboveground green biomass ( $g$ dry weight $\left.\mathrm{m}^{-2}\right)$, and $\mathrm{W}$ is the soil volumetric water content at $3 \mathrm{~cm}$ depth $\left(\mathrm{m}^{3} \mathrm{~m}^{-3}\right)$. Since the right side of Eq. 3 contained only positive values, the residuals were transformed by adding 2.0.

The temperature sensitivity of $\mathrm{R}_{\mathrm{eco}}\left(\mathrm{Q}_{10}\right)$ was expressed as a linear function of soil water content,

$$
\mathrm{Q}_{10}=\mathrm{a}_{6} \mathrm{~W}+\mathrm{a}_{7}
$$


Parameters for the model are listed in Table 1 . The model was validated by comparing the observed and modeled values $\left(r^{2}=0.754\right.$; Fig. 6 in Nakano \& Shinoda, 2010). We adopted this model only for the growing season from May to September because ecosystem respiration during the winter and freeze-thaw cycles in the early spring and late fall might be controlled by different factors.

\begin{tabular}{ccc}
\hline & Parameter & Value \\
\hline Eq2 & $\mathrm{a}_{1}$ & 0.0289 \\
& $\mathrm{a}_{2}$ & 0.558 \\
\hline Eq3 & $\mathrm{a}_{3}$ & -142 \\
& $\mathrm{a}_{4}$ & 31.9 \\
& $\mathrm{a}_{5}$ & -0.403 \\
Eq4 & $\mathrm{a}_{6}$ & 3.72 \\
& $\mathrm{a}_{7}$ & 1.51 \\
\hline
\end{tabular}

Table 1. Parameters of the $R_{\text {eco }}$ model. Values cited are from Nakano \& Shinoda (2010)

In the present study, $\mathrm{CO}_{2}$ effluxes during the growing season (May-September) from 2007 to 2010 at site BU were calculated from the observed soil temperature data at a depth of 5 $\mathrm{cm}$ and soil volumetric water content (VWC) at $5 \mathrm{~cm}$ depth, which were sampled every 30 minutes. We confirmed the absence of a significant difference between VWCs at $3 \mathrm{~cm}$ depth and those at $5 \mathrm{~cm}$ depth, and thus the values at $5 \mathrm{~cm}$ depth were used in the model.

Since AGB was not continuously measured at site BU, temporal changes in AGB were estimated from a remotely sensed vegetation index. The normalized difference vegetation index (NDVI) from the MODIS/Terra satellite was used in this study because NDVI is commonly applied to estimate the vegetation productivity of terrestrial ecosystems (Nemani et al., 2003; Running et al., 2004). We downloaded the 8-day Land Surface Reflectance (MOD09A1) data sets from the Land Processes Distributed Active Archive Center (LP DAAC), US Geological Survey (http://lpdaac.usgs.gov) and calculated NDVI values as follows:

$$
\text { NDVI }=\left(\rho_{\text {nir }}-\rho_{\text {red }}\right) /\left(\rho_{\text {nir }}+\rho_{\text {red }}\right),
$$

where $\rho_{\text {nir }}$ and $\rho_{\text {red }}$ are the reflectances of near-infrared and red bands, respectively.

Green parts of the plants were clipped in four to ten $1 \times 1-\mathrm{m}$ quadrats at sites BU, NB, and SB in 2009 and 2010, and the AGB was determined by oven-drying and weighing the clippings. Average AGB values were calculated for each site and each year. Figure 2 shows the relationship between the average AGB and NDVI at the same times and locations as the field measurements. The AGB values showed a strong positive correlation with NDVI $\left(r^{2}=\right.$ $0.849, P<0.001)$. Using this relationship, temporal changes in AGB for every 8-day interval at site BU were estimated from the NDVI data, and daily values were interpolated from the 8-day values. 


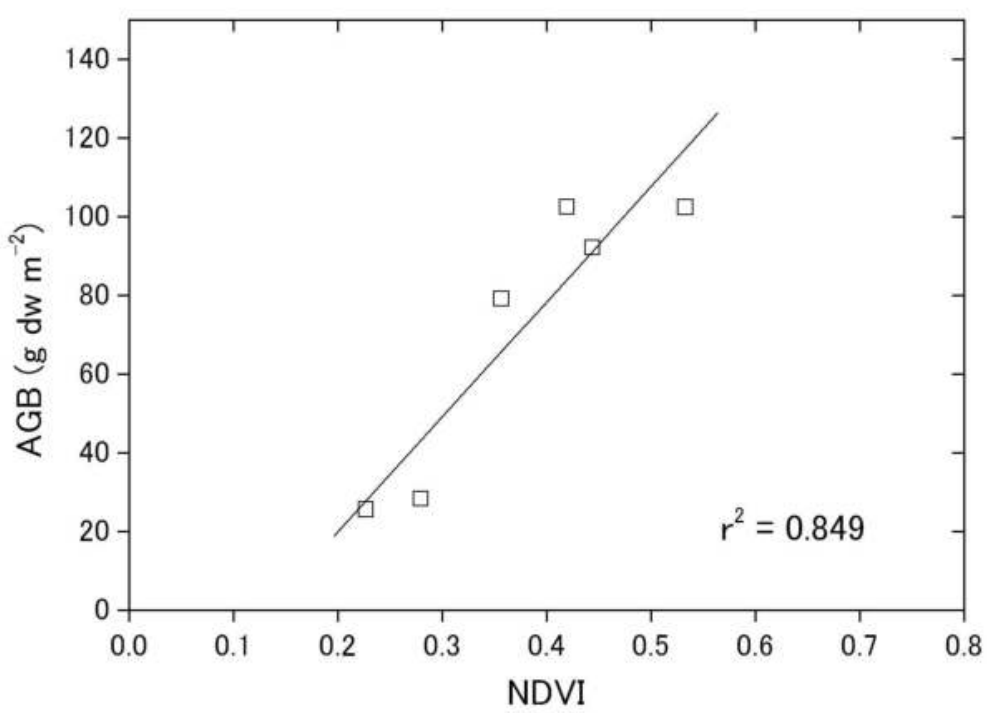

Fig. 2. Relationship between the aboveground biomass (AGB) measured at sites BU, NB, and $\mathrm{SB}$ and the normalized difference vegetation index (NDVI) obtained from satellite remote sensing data. The solid line is the linear regression line

\section{Results and discussion}

\subsection{Meteorology and plant biomass}

The monthly variations in air temperature, precipitation, and soil volumetric water content (VWC) values during 2007-2010 are shown in Fig. 3, and plant AGB derived from 8-day NDVI data is given in Fig. 4. Monthly mean air temperature was $>0{ }^{\circ} \mathrm{C}$ from April to October, reaching the maximum in July of every year. Average temperature during the growing season (May-September) was $17.8^{\circ} \mathrm{C}$ in $2007,15.4^{\circ} \mathrm{C}$ in $2008,15.5^{\circ} \mathrm{C}$ in 2009 , and $16.4^{\circ} \mathrm{C}$ in 2010 (Table 2). The amount and timing of precipitation differed markedly among years; e.g., in 2007, the cumulative precipitation during the growing season was $79.3 \mathrm{~mm}$, less than half of that in 2009 (178.1 mm) (Table 2). In June and July 2007, precipitation was considerably lower than in the other years, resulting in an extremely low AGB during the entire 2007 growth season (Fig. 4). A great deal of rain fell in the early 2008 growing season (June), with even more rain in the late 2009 growing season (August). This resulted in high VWC values for June $2008\left(0.067 \mathrm{~m}^{3} \mathrm{~m}^{-3}\right)$ and August $2009\left(0.078 \mathrm{~m}^{3} \mathrm{~m}^{-3}\right)$. Large amount of precipitation and high soil moisture in the early growing season of 2008 stimulated plant growth and increased AGB rapidly. As a consequence, the average AGB during the whole growing season was highest in 2008 (Table 2), although 2008 was not the wettest year. In 2010, the cumulative precipitation and average soil water content throughout the growing season were relatively low. However, a great deal of rain fell in July of that year, and subsequently, the amount of plant biomass rapidly increased in early July. Thus, the average AGB for 2010 was similar to that of 2009. 

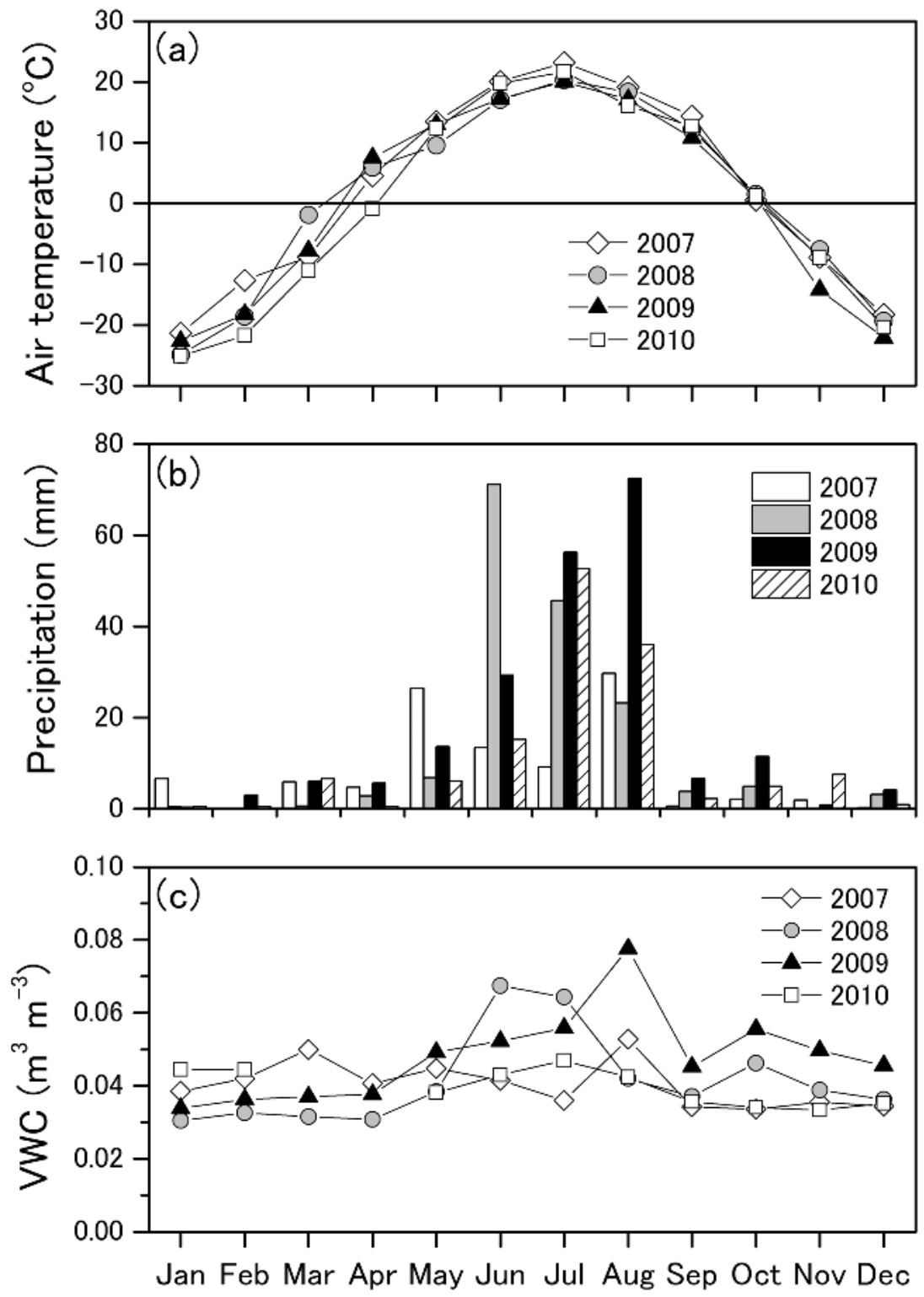

Fig. 3. Variation in (a) monthly mean air temperature, (b) monthly precipitation, and (c) monthly mean soil volumetric water content (VWC) from 2007 to 2010 at site BU 


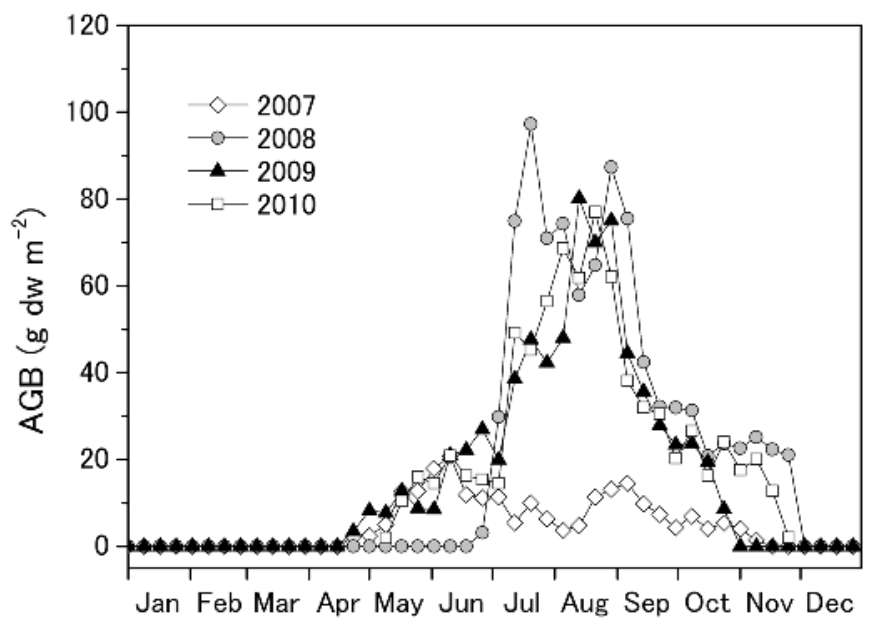

Fig. 4. Time course of live aboveground biomass (AGB) derived from the remotely sensed NDVI data

\subsection{Estimation of ecosystem respiration}

The half-hourly rate of $R_{\text {eco }}$ was calculated using our empirical respiration model, and the daily flux was determined (Fig. 5). Variation in the daily rate of $R_{\text {eco }}$ appeared to coincide with fluctuations in VWC caused by rain events. Yearly maxima of the daily $R_{\text {eco }}$ were $2.7 \mathrm{~g}$ $\mathrm{C} \mathrm{m}^{-2} \mathrm{~d}^{-1}$ in 2007, $4.9 \mathrm{~g} \mathrm{C} \mathrm{m}^{-2} \mathrm{~d}^{-1}$ in 2008, $4.7 \mathrm{~g} \mathrm{C} \mathrm{m}^{-2} \mathrm{~d}^{-1}$ in 2009, and $4.3 \mathrm{~g} \mathrm{C} \mathrm{m}^{-2} \mathrm{~d}^{-1}$ in 2010. Cumulative rates of ecosystem respiration during the growing season are listed in Table 2. The maximum and minimum amounts of ecosystem respiration within the 4 years were observed in 2009 and 2007, the wettest and driest years, respectively. Studies on ecosystem respiration in grassland ecosystems have indicated that respiratory efflux is generally larger in wet years than in dry years (Aires et al., 2008; Meyers, 2001).

\begin{tabular}{lcccc}
\hline & 2007 & 2008 & 2009 & 2010 \\
\hline Air temperature $\left({ }^{\circ} \mathrm{C}\right)$ & 17.8 & 15.4 & 15.5 & 16.4 \\
Precipitaion $(\mathrm{mm})$ & 79.3 & 150.5 & 178.1 & 112.1 \\
AGB $\left(\mathrm{g} \mathrm{dw} \mathrm{m}^{-2}\right)$ & 14.0 & 39.9 & 37.7 & 37.3 \\
VWC $\left(\mathrm{m}^{3} \mathrm{~m}^{-3}\right)$ & 0.042 & 0.050 & 0.056 & 0.043 \\
Soil temperature $\left({ }^{\circ} \mathrm{C}\right)$ & 21.2 & 17.9 & 18.4 & 19.1 \\
$\mathrm{R}_{\text {eco }}\left(\mathrm{g} \mathrm{C} \mathrm{m}^{-2}\right)$ & 155.4 & 286.6 & 295.0 & 222.8 \\
\hline
\end{tabular}

Table 2. Average air temperature, cumulative precipitation, average aboveground green biomass (AGB), average soil volumetric water content (VWC), average soil temperature at 5 cm depth $\left(\mathrm{T}_{\mathrm{s}}\right)$, and cumulative rate of ecosystem respiration $\left(\mathrm{R}_{\mathrm{eco}}\right)$ during the growing season (i.e., May-September) from 2007 to 2010 

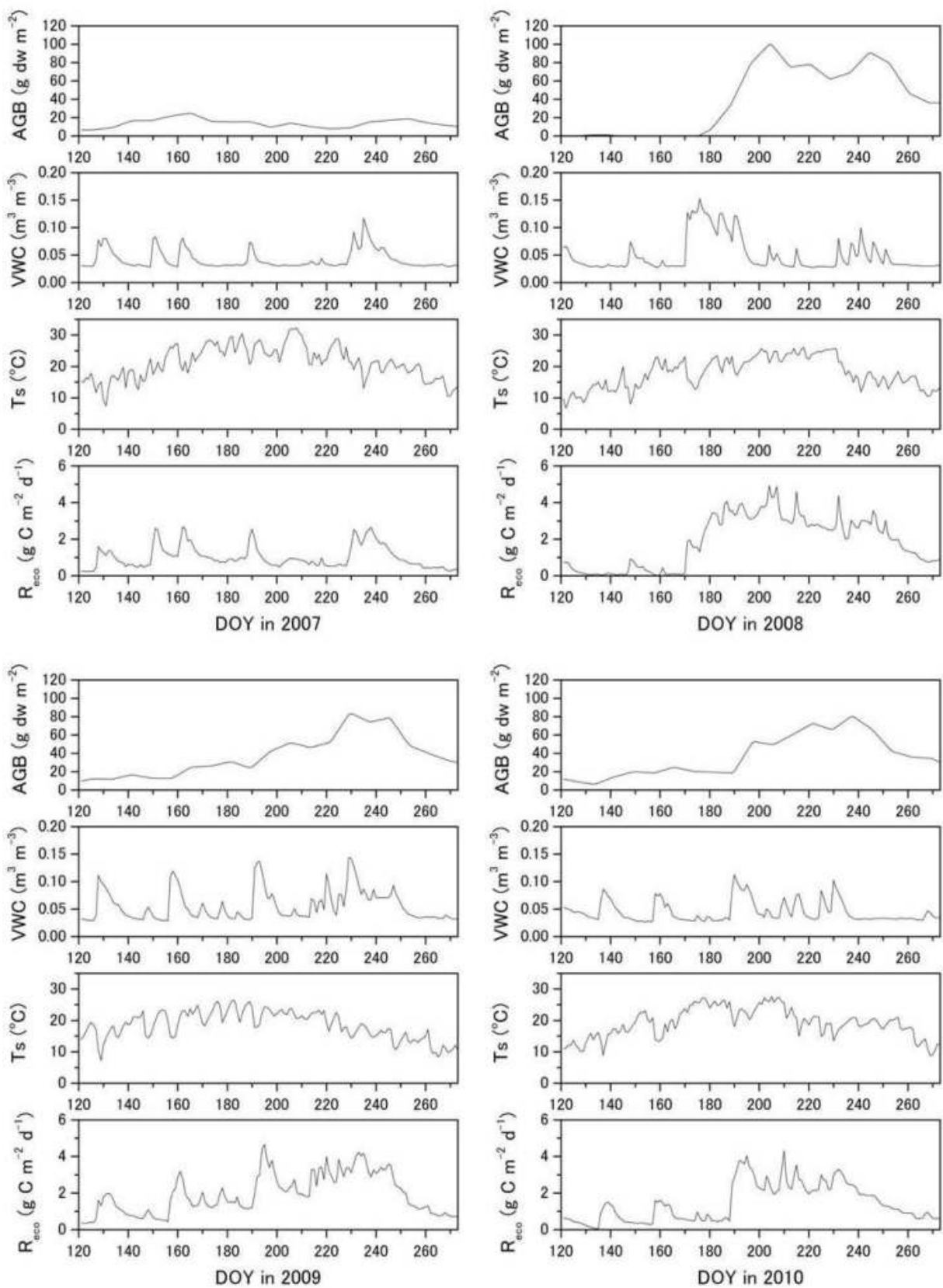

Fig. 5. Temporal variation in daily values of the aboveground biomass (AGB), soil volumetric water content at $5 \mathrm{~cm}$ depth (VWC), soil temperature at $5 \mathrm{~cm}$ depth $\left(\mathrm{T}_{\mathrm{s}}\right)$, and ecosystem respiration ( $R_{\text {eco }}$ ) during the growing season (i.e., May-September) from 2007 to 2010 


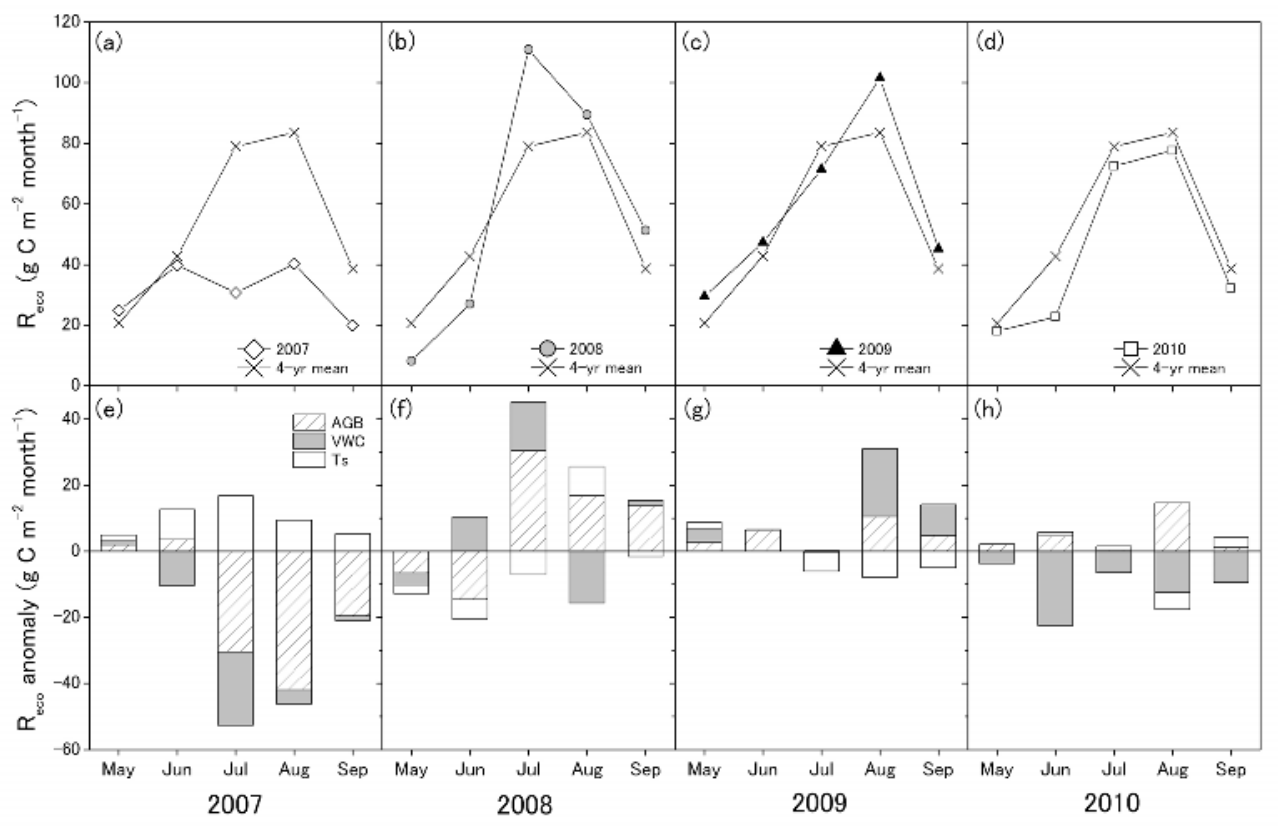

Fig. 6. (a-d) Monthly rate of ecosystem respiration $\left(\mathrm{R}_{\mathrm{eco}}\right)$ and virtual $\mathrm{R}_{\text {eco }}$ calculated from the 4-year mean values of the aboveground biomass (AGB), soil volumetric water content at 5 $\mathrm{cm}$ depth (VWC), and soil temperature at $5 \mathrm{~cm}$ depth $\left(\mathrm{T}_{\mathrm{s}}\right)$. (e-h) Components of the controlling factors of the anomalous $R_{\text {eco }}$ values

To clarify the individual effects of AGB, VWC, and soil temperature $\left(\mathrm{T}_{\mathrm{s}}\right)$ on the interannual variation in ecosystem respiration, we computed the average rate of $\mathrm{R}_{\text {eco }}$ using the 4-year mean values of $\mathrm{AGB}, \mathrm{VWC}$, and $\mathrm{T}_{\mathrm{s}}$ measured every 30 minutes (Fig. 6a-d), and the significance of the anomalous values was assessed. To examine the effect of a single parameter, $R_{\text {eco }}$ was calculated by setting the remaining parameters as equivalent to the mean values. This process allowed us to measure how ecosystem respiration responded to variations in AGB, VWC, and $\mathrm{T}_{\mathrm{s}}$. Fig. 6e-h shows the contribution of each parameter (AGB, VWC, and $\mathrm{T}_{\mathrm{s}}$ ) to the anomalous $\mathrm{R}_{\text {eco }}$ values. In 2007, the soil temperature was higher than in other years, and soil water content and plant biomass were lower. While the higher temperature increased the rate of ecosystem respiration, depression of $R_{\text {eco }}$ by the drier soil and less plant biomass were much more significant. A decrease in AGB accounted for the greatest proportion of the $R_{\text {eco }}$ depression, particularly in August and September. Consequently, the total amount of ecosystem respiration in 2007 was considerably lower than the average rate. In 2009, the high soil water content in August and September was correlated with the large amount of total ecosystem respiration during the growing season. Low soil water content decreased the $R_{\text {eco }}$ in 2010, whereas plant biomass values were slightly higher and compensated for the depression in respiration influenced by the soil water content. In general, ecosystem respiration is considered to be a function of 
temperature. However, the results of this study suggest that variations in soil water content and plant biomass are more important determinants of the interannual variation in ecosystem respiration in semiarid grasslands.

Recent field-based studies have indicated the importance of plant photosynthetic productivity in the variability of carbon dynamics in grassland ecosystems. Aires et al. (2008) carried out the eddy-covariance measurements of $\mathrm{CO}_{2}$ flux over a Mediterranean grassland in Portugal during dry and normal years and revealed that variations in ecosystem respiration were mainly controlled by canopy photosynthesis. Shimoda et al. (2009) suggested that large biomass contributes to the higher respired carbon loss over a temperate grassland in Japan. Craine et al. (1999) examined the role of a decreased carbohydrate source on soil respiration in an annually-burned grassland through manipulations of light intensity and the removal of aboveground biomass. They showed that shading and clipping grasses caused $40 \%$ and $19 \%$ reductions in soil $\mathrm{CO}_{2}$ flux, respectively. A model study also demonstrated that a model using only climate drivers as predictors of $R_{\text {eco }}$ failed to describe part of the temporal variability in the data and that dependency on grass primary production needed to be included as an additional driver of $R_{\text {eco }}$ (Migliavacca et al., 2011). Several studies have conducted rainfall manipulation experiments to examine how the magnitude and timing of rainfall affect the ecosystem and soil respiration (e.g., Cable et al. 2008; Chou et al. 2008; Liu et al., 2002; Thomey et al., 2011). Chou et al. (2008) found that soil respiration was more sensitive to rainy season length than to the quantity of rainfall over a Californian annual grassland. Thomey et al. (2011) demonstrated that a single large rainfall led to a significant increase in soil respiration and the strength of these patterns differed between years in a desert grassland in New Mexico. In agreement with these studies, our results indicated that the effect of aboveground biomass and soil water content was larger than that of soil temperature on the interannual variation in ecosystem respiration and that contribution of plant AGB and soil water content to the respiration variability differed from year to year.

\section{Conclusions}

Interannual variations in ecosystem respiration over 4 years, including several hydrologically contrastive years, were computed by inputting observed meteorological parameters and remotely sensed plant biomass data into the empirical respiration model. The total amount of ecosystem respiration was highest in the wettest year (2009) and lowest in the driest year (2007). We examined the effects of plant AGB, soil water content, and soil temperature on the variation in ecosystem respiration. Ecosystem respiration is generally regarded as a function of temperature, whereas the results of this study suggest that the variations in soil water content and plant biomass are more important controls for interannual ecosystem respiration variation in semiarid grasslands.

\section{Acknowledgment}

We thank Ganbat Bavuudorj from the Institute of Meteorology and Hydrology of Mongolia for his help in field measurements. This research was funded by Chuo University (Grant for Special Research) and the Ministry of Education, Culture, Sports, Science and Technology, Japan (Grants-in-Aid nos. 20255001 and 22510017). 


\section{References}

Aires, L.M.I., Pio, C.A., \& Pereira, J.S. (2008). Carbon dioxide exchange above a Mediterranean C3/C4 grassland during two climatologically contrasting years. Global Change Biol., Vol. 14, pp. 539-555.

Cable, J.M., Ogle, K., Williams, D.G., Weltzin, J.F., \& Huxman, T.E. (2008). Soil texture drives responses of soil respiration to precipitation pulses in the Sonoran desert: implications for climate change. Ecosystems, Vol. 11, pp. 961-979.

Chou, W.W., Silver, W.L., Jackson, R.D., Thompson, A.W., \& Allen-Diaz, B. (2008). The sensitivity of annual grassland carbon cycling to the quantity and timing of rainfall. Global Change Biol., Vol. 14, pp. 1382-1394.

Craine, J.M., Wedin, D.A., \& Chapin III, F.S. (1999). Predominance of ecophysiological controls on soil $\mathrm{CO}_{2}$ flux in a Minnesota grassland. Plant and Soil, Vol. 207, pp. 77-86.

Davidson, E.A., Belk, E., \& Boone, R.D. (1998). Soil water content and temperature as independent or confound factors controlling soil respiration in a temperate mixed hardwood forest. Global Change Biol., Vol. 4, pp. 217-227.

Fang, C. \& Moncrieff, J.B. (2001). The dependence of soil $\mathrm{CO}_{2}$ efflux on temperature. Soil Biol. Biochem., Vol. 33, pp. 78-90.

Gaumont-Guay, D., Black, T.A., Griffis, T.J., Barr, A.G., Jassal, R.S., \& Nesic, Z. (2006). Interpreting the dependence of soil respiration on soil temperature and water content in a boreal aspen stand. Agric. For. Meteorol., Vol. 140, pp. 220-235.

Hunt, J.E., Kelliher, F.M., McSeveny, T.M., \& Byers, J.N. (2002). Evaporation and carbon dioxide exchange between the atmosphere and a tussock grassland during a summer drought. Agric. For. Meteorol., Vol. 111, pp. 65-82.

IUSS Working Group WRB (2006). World reference base for soil resources 2006. 2nd edition. World Soil References Reports 103, FAO, Rome.

Jassal, R.S., Black, T.A., Novak, M.D., Gaumont-Guay, D., \& Nesic, Z. (2008). Effect of soil water stress on soil respiration and its temperature sensitivity in an 18-year-old temperate Douglas-fir stand. Global Change Biol., Vol. 14, pp. 1-14.

Liu, X., Wan, S., Su, B., Hui, D., \& Luo, Y. (2002). Response of soil $\mathrm{CO}_{2}$ efflux to water manipulation in a tallgrass prairie ecosystem. Plant and Soil, Vol. 240, pp. 213-223.

Lloyd, J. \& Taylor, J.A. (1994). On the temperature dependence of soil respiration. Funct. Ecol., Vol. 8, pp. 315-323.

Meyers, T.P. (2001). A comparison of summertime water and $\mathrm{CO}_{2}$ fluxes over rangeland for well watered and drought conditions. Agric. For. Meteorol, Vol. 106, pp. 205-214.

Migliavacca, M., Reichstein, M., Richardson, A.D., Colombo, R., Sutton, M.A., Lasslop, G., Tomelleri, E., Wohlfahrt, G., Carvalhais, N., Cescatti, A., Mahecha, M.D., Montagnani, L., Papale, D., Zaehle, S., Arain, A., Arneth, A., Black, T.A., Carrara, A., Dore, S., Gianelle, D., Helfter, C., Hollinger, D., Kutsch, W.L., Lafleur, P.M., Nouvellon, Y., Rebmann, C., Rocha, H.R.Da., Rodeghiero, M., Roupsard, O., Sebasti, M.T., Seufert, G., Soussana, J.F., \& Van Der Molen, M.K. (2011). Semiempirical modeling of abiotic and biotic factors controlling ecosystem respiration across eddy covariance sites. Global Change Biol., Vol. 17, pp. 390-409.

Miyazaki, S., Yasunari, T., Miyamoto, T., Kaihotsu, I., Davaa, G., Oyunbaatar, D., Natsagdorj, L., \& Oki, T. (2004). Agrometeorological conditions of grassland 
vegetation in central Mongolia and their impact for leaf area growth. J. Geophys. Res., Vol. 109, D22106, doi:101029/2004JD005179.

Nakano, T., Nemoto, M., \& Shinoda, M. (2008). Environmental controls on photosynthetic production and ecosystem respiration in semi-arid grasslands of Mongolia. Agric. For. Meteorol, Vol. 148, pp. 1456-1466.

Nakano, T. \& Shinoda, M. (2010). Response of ecosystem respiration to soil water and plant biomass in a semiarid grassland. Soil Sci. Plant Nutr., Vol. 56, pp. 773-781.

Nemani, R.R., Keeling, C.D., Hashimoto, H., Jolly, W.M., Piper, S.C., Tucker, C.J., Myneni, R.B., \& Running S.W. (2003). Climate-driven increases in global terrestrial net primary production from 1982 to 1999. Science, Vol. 300, pp. 1560-1563.

Ni, J. (2003). Plant functional types and climate along a precipitation gradient in temperate grasslands, north-east China and south-east Mongolia. J. Arid Environ., Vol. 53, pp. 501-516.

Running, S.W., Nemani, R.R., Heinsch, F.A., Zhao, M.S., Reeves, M., \& Hashimoto, H. (2004). A continuous satellite-derived measure of global terrestrial primary production. Bioscience, Vol. 54, pp. 547-560.

Sampson, D.A., Janssens, I.A., Curiel Yuste, J., \& Ceulemans, R. (2007). Basal rates of soil respiration are correlated with photosynthesis in a mixed temperate forest. Global Change Biol., Vol. 13, pp. 2008-2017.

Shimoda, S., Lee, G., Yokoyama, T., Liu, J., Saito, M., \& Oikawa, T. (2009). Response of ecosystem $\mathrm{CO} 2$ exchange to biomass productivity in a high yield grassland. Environ. Exp. Bot., Vol. 65, pp. 425-431.

Shinoda, M., Nachinshonhor, G.U., \& Nemoto, M. (2010). Impact of drought on vegetation dynamics of the Mongolian Steppe: A field experiment. J. Arid Envioron., Vol. 74, pp. 63-69.

Thomey, M.L., Collins, S.L., Vargas, R., Johnson, J.E., Brown, R.F., Natvig, D.O., \& Friggens, M.T. (2011). Effect of precipitation variability on net primary production and soil respiration in a Chihuahuan Desert grassland. Global Change Biol., Vol. 17, pp. 1505-1515.

Wen, X.F., Yu, G.R., Sun, X.M., Li, Q.K., Liu, Y.F., Zhang, L.M., Ren, C.Y., Fu, Y.L., \& Li, Z.Q. (2006). Soil moisture effect on the temperature dependence of ecosystem respiration in a subtropical Pinus plantation of southeastern China. Agric. For. Meteorol., Vol. 137, pp. 166-175.

$\mathrm{Xu}, \mathrm{M}$. \& Qi, Y. (2001). Soil-surface $\mathrm{CO}_{2}$ efflux and its spatial and temporal variations in a young ponderosa pine plantation in northern California. Global Change Biol., Vol. 7, pp. 667-677. 


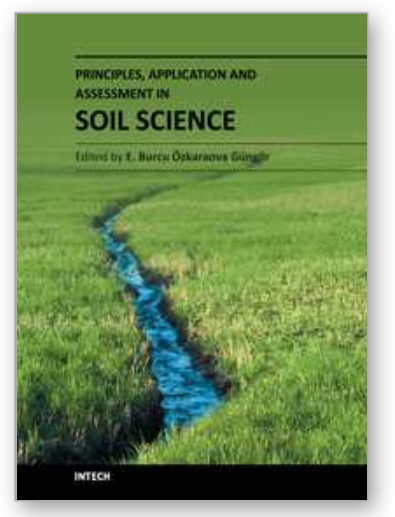

\author{
Principles, Application and Assessment in Soil Science \\ Edited by Dr. Burcu E. Ozkaraova Gungor
}

ISBN 978-953-307-740-6

Hard cover, 394 pages

Publisher InTech

Published online 22, December, 2011

Published in print edition December, 2011

Our dependence on soil, and our curiosity about it, is leading to the investigation of changes within soil processes. Furthermore, the diversity and dynamics of soil are enabling new discoveries and insights, which help us to understand the variations in soil processes. Consequently, this permits us to take the necessary measures for soil protection, thus promoting soil health. This book aims to provide an up-to-date account of the current state of knowledge in recent practices and assessments in soil science. Moreover, it presents a comprehensive evaluation of the effect of residue/waste application on soil properties and, further, on the mechanism of plant adaptation and plant growth. Interesting examples of simulation using various models dealing with carbon sequestration, ecosystem respiration, and soil landscape, etc. are demonstrated. The book also includes chapters on the analysis of areal data and geostatistics using different assessment methods. More recent developments in analytical techniques used to obtain answers to the various physical mechanisms, chemical, and biological processes in soil are also present.

\title{
How to reference
}

In order to correctly reference this scholarly work, feel free to copy and paste the following:

Tomoko Nakano and Masato Shinoda (2011). Modeling of the Interannual Variation in Ecosystem Respiration of a Semiarid Grassland, Principles, Application and Assessment in Soil Science, Dr. Burcu E. Ozkaraova Gungor (Ed.), ISBN: 978-953-307-740-6, InTech, Available from: http://www.intechopen.com/books/principlesapplication-and-assessment-in-soil-science/modeling-of-the-interannual-variation-in-ecosystem-respiration-ofa-semiarid-grassland

\section{INTECH}

open science | open minds

\section{InTech Europe}

University Campus STeP Ri

Slavka Krautzeka 83/A

51000 Rijeka, Croatia

Phone: +385 (51) 770447

Fax: +385 (51) 686166

www.intechopen.com

\section{InTech China}

Unit 405, Office Block, Hotel Equatorial Shanghai

No.65, Yan An Road (West), Shanghai, 200040, China 中国上海市延安西路65号上海国际贵都大饭店办公楼 405 单元

Phone: +86-21-62489820

Fax: +86-21-62489821 
(C) 2011 The Author(s). Licensee IntechOpen. This is an open access article distributed under the terms of the Creative Commons Attribution 3.0 License, which permits unrestricted use, distribution, and reproduction in any medium, provided the original work is properly cited. 